\title{
KEMAMPUAN MALARISIDAL NANOPARTIKEL EKSTRAK DAUN JUWET (Syzygium cumini) SEBAGAI TERAPI AJUVAN PADA HISTOPATOLOGI HATI MENCIT (Mus musculus) PENDERITA MALARIA
}

\section{MALARICIDAL ABILITY OF JUWET (Syzygium cumini) LEAF EXTRACT NANOPARTICLE AS ADJUVANT THERAPY ON LIVER HISTOPATHOLOGY OF MALARIA MICE (Mus musculus)}

\author{
Mahendra Pujiyanto 1), Lilik Maslachah 2), Nusdianto Triakoso 2), \\ Mochamad Lazuardi 2), Chairul Anwar 2), Djoko Legowo 2) \\ 1) Mahasiswa, 2) Dosen \\ Fakultas Kedokteran Hewan Universitas Airlangga \\ Kampus C UNAIR, Jl. Mulyorejo-Surabaya 60115 \\ Telp. 031-5992785, Fax. 031-5993015 \\ Email: jbmvunair@gmail.com
}

\begin{abstract}
The aimed of this study is to know malaricidal ability of nanoparticle juwet (Syzygium cumini) leaf extract as adjuvant therapy on liver histopathological of mice (Mus musculus) which infected by Plasmodium berghei. This research uses 30 mice which are divided into six treatment groups namely K0 (not infected without treated), K+ (infected without treated), K1 (infected and treated with chloroquin), K2 (infected and treated with juwet leaf extract), P1 (infected and treated with juwet leaf extract nanoparticle) and P2 (infected and combination treated with chloroquine and juwet leaf extract nanoparticle) which infected by $1 \times 10^{5} \mathrm{in} 0.2 \mathrm{ml}$ of Plasmodium berghei. The data were analyzed by Kruskal Wallis using SPSS and followed with Mann-Whitney test. This research result showed there was significant difference $(p<0.05)$ between K1 and P2, but did not showed significant difference $(p>0.05)$ with $K+, K 2$ and P1. Based on this research, it could be concluded that nanoparticle juwet (Syzygium cumini) leaf extract as adjuvant therapy estimated can increase malaricidal ability in degeneration, necrosis, portal inflammation, Kupffer cell hyperplasia, sinusoidal congestion, and hemosiderosis in mice liver which infected by Plasmodium berghei.
\end{abstract}

Key words: Syzygium cumini, Nanoparticle, Adjuvant therapy, Liver, Plasmodium berghei.

\section{PENDAHULUAN}

Malaria merupakan penyakit yang disebabkan oleh Plasmodium yang ditularkan oleh nyamuk Anopheles spp (Weeratunga, et al., 2016). Hepar merupakan target organ yang memiliki peranan penting dalam siklus malaria (Soulard, et al., 2015). Infeksi Plasmodium dapat meningkatkan radikal bebas dan aktivasi sel inflamasi yang menghasilkan reactive oxygen species (ROS) berlebih (Harlev, et al., 2015). Hingga saat ini pengobatan penyakit malaria menggunakan obat klorokuin yang bekerja pada tahap siklus intraeritrositik selama parasit aktif mendegradasi hemoglobin (Parhizgar and Tahghighi, 2017). Infeksi plasmodium dapat berakibat fatal karena dapat menyebabkan komplikasi malaria berat, maka dari itu perlu diberikan terapi ajuvan untuk meningkatkan efektifitas kerja obat antimalaria primer serta mengurangi komplikasi yang lebih berat terkait penyakit malaria (Varo, et al., 2018). Salah satunya dengan pemberian daun juwet (Syzygium cumini) yang merupakan antioksidan yang baik karena mengandung flavonoid, asam fenolik, tanin dan terpenoid, selain itu kandungan tersebut memiliki aktivitas 
sebagai antiplasmodial (Yasueda, et al., 2015; Resna, 2017). Akan tetapi senyawa bahan alam memiliki kelarutan yang rendah dalam air serta kurangnya permeabilitas menembus barrier absorbsi, pengecilan ukuran partikel akan menyebabkan peningkatan luas permukaan yang menyebabkan kecepatan absorbsi oleh saluran cerna meningkat sehingga bioavailabilitasnya pun akan meningkat (Ramadon dan Mun'im, 2016; Bilia, et al., 2014).

\section{MATERI DAN METIODE PENELITIAN}

\section{Tempat dan Waktu Penelitian}

Penelitian ini dilakukan di beberapa laboratorium yang berbeda. Pengeringan dan penggilingan daun juwet dilakukan di Laboratorium Pakan Ternak Fakultas Kedokteran Hewan Universitas Airlangga. Pembuatan ekstrak daun juwet dilakukan di Laboratorium Farmakologi Fakultas Kedokteran Hewan Universitas Airlangga. Pembuatan dan pemeriksaan sediaan histopatologi dilakukan di Laboratorium Patologi Veteriner Fakultas Kedokteran Hewan Universitas Airlangga. Pembuatan sediaan nanopartikel ekstrak daun juwet dilakukan di Laboratorium Biomolekuler Fakultas Kedokteran Hewan Universitas Airlangga. Pemeriksaan ukuran sediaan nanopartikel dilakukan di Fakultas Teknik Mesin Institut Teknologi Sepuluh November Surabaya. Pembuatan sediaan obat dilakukan di Laboratorium Ilmu Farmasi Veteriner Fakultas Kedokteran Hewan Universitas Airlangga. Pemeliharaan serta pemberian perlakuan mencit dilakukan di Kandang Hewan Coba Universitas Airlangga Surabaya. Penelitian ini dilakukan pada bulan Juli 2018 sampai November 2018.

\section{Alat dan Bahan}

Peralatan penelitian yang digunakan adalah kandang hewan coba beserta penutup kawat, sekat, tempat makan dan minum mencit, kertas undian, thermometer, spuit tuberkulin, sonde mencit, mikro pipet, mikrotube $1,5 \mathrm{ml}$, pipet pasteur, vacutainer, mesin sentrifuge, Improved Neubauer Counting Chamber, mesin penggiling, blender kering, alat rotary evaporator bath, baskom, sendok, toples besar, magnetic stirrer, sonikator, gelas ukur ( $250 \mathrm{ml}$ dan $100 \mathrm{ml})$, gelas beaker $(500 \mathrm{ml}$ dan $200 \mathrm{ml})$, penjepit kayu, alumunium foil, tabung reaksi, almari pendingin, alat freeze dryer, neraca analitik, sudip, alat scanning electron microscope (SEM), cawan penguap, mortar, stamper, batang pengaduk, spatel, kertas perkamen, kertas label, botol obat, petri dish, sarung tangan latek, masker, papan preparasi, jarum pentul, alat bedah minor, pot sampel, alat mikrotom, object glass, cover glass, kotak sediaan histopatologi, staining jar, counter, dan mikroskop.

Penelitian ini menggunakan daun juwet (Syzygium cumini), ethanol Pro Analisis (PA) 96\%, NaTTP (Natrium Tripolyphosphate), kitosan, larutan buffer asetat $2 \%$ dengan $\mathrm{pH} 4$, es serut, aquades, CMC-Na, klorokuin, mencit (Mus musculus), pakan mencit berupa pellet ayam, serbuk kayu, pewarna asam sitrat, Phosphate Buffer Saline (PBS), elsevier, serbuk EDTA, Plasmodium berghei strain ANKA dari LPT bagian laboratorium malaria, cat giemsa, oil emersi, aquades steril, methanol 96\%, alkohol 70\%, ketamin 10\%, hepar yang terinfeksi Plasmodium berghei, formalin $10 \%$, pewarna Haematocylin Eosin (HE), larutan FFA (formaldehyde: acetic acid: alcohol), larutan xylol, larutan alkohol bertingkat $(70 \%, 80 \%, 90 \%, 95 \%)$, alkohol absolut, cairan parafin, albumin, dan gliserin. 


\section{Prosedur Penelitian}

Pada penelitian ini digunakan mencit (Mus musculus) sebagai hewan coba sebanyak 30 ekor yang dibagi menjadi 6 perlakuan yaitu K0 yang tidak diinfeksi dan diberi pelarut obat, $\mathrm{K}+$ yang diinfeksi dan diberi pelarut obat, K1 yang diinfeksi dan diterapi ekstrak daun juwet, P1 yang diinfeksi dan diterapi nanopartikel ekstrak daun juwet, P2 yang diinfeksi dan diterapi klorokuin serta nanopartikel ekstrak daun juwet. Terapi dilakukan selama empat hari, 24 jam pasca infeksi. Pada hari ke-15 pasca infeksi, mencit dieutanasi dan organ hepar dikoleksi untuk dibuat preparat histopatologi.

\section{HASIL PENELITIAN}

Pengamatan histopatologi hepar mencit berupa degenerasi dan nekrosis sel hepar, inflamasi portal, hiperplasia sel Kupffer, kongesti sinusoid, serta hemosiderosis dengan cara skoring. Skoring histopatologi hepar dengan cara mengamati lesi yang terdapat dalam satu lapang pandang dan dilakukan pengulangan pada lima lapang pandang berbeda dalam satu sediaan histopatologi. Sediaan histopatologi didapatkan dari organ hepar mencit yang diinfeksi dengan Plasmodium berghei beserta perlakuan tiap kelompok dan dibuat sediaan histopatologi menggunakan pewarnaan Haematoxylin Eosin (HE). Perubahan histopatologi diamati menggunakan mikroskop Olympus dengan fasilitas pendukung Optilab Viewer dengan perbesaran 400× (lensa objektif 40× dan lensa okuler 10×).

Pemeriksaan histopatologi hepar dengan cara melihat preparat di bawah mikroskop perbesaran 400×, preparat difoto pada daerah vena porta dan vena sentralis, zona dua, dan area segitiga Kiernan's (portal area). Selanjutnya dilakukan skoring degenerasi dan nekrosis sel hepar pada daerah vena sentralis dan vena porta. Skoring hiperplasia sel Kupffer, kongesti sinusoid, serta hemosiderosis pada zona dua, dan skoring inflamasi portal pada area segitiga Kiernan's (area portal).

Hasil penelitian menunjukkan bahwa terdapat perbedaan yang nyata $(\mathrm{p}<0,05)$ antara perlakuan K1 dan P2, akan tetapi tidak menunjukkan perbedaan yang nyata $(p>0,05)$ pada perlakuan $\mathrm{K}+$, $\mathrm{K} 2$, dan P1.

Berdasarkan analisis statistik nonparametrik Kruskal Wallis, derajat kerusakan hepar menunjukkan ada perbedaan nyata sehingga pengujian dilanjutkan dengan uji Mann-Whitney. Hasil uji Mann-Whitney derajat kerusakan hepar tercantum pada tabel 4.1

Tabel 4.1 Jumlah Rata-rata Derajat Kerusakan Hepar Mencit

\begin{tabular}{|c|c|}
\hline Perlakuan & Rerata \pm Simpangan Baku \\
\hline K0 & $0,12^{\mathrm{a}} \pm 0,014$ \\
\hline K+ & $2,43^{\mathrm{d}} \pm 0,248$ \\
\hline K1 & $0,36^{\mathrm{b}} \pm 0,086$ \\
\hline K2 & $2,08^{\mathrm{d}} \pm 0,184$ \\
\hline P1 & $2,33^{\mathrm{d}} \pm 0,236$ \\
\hline P2 & $0,62^{\mathrm{c}} \pm 0,089$ \\
\hline
\end{tabular}



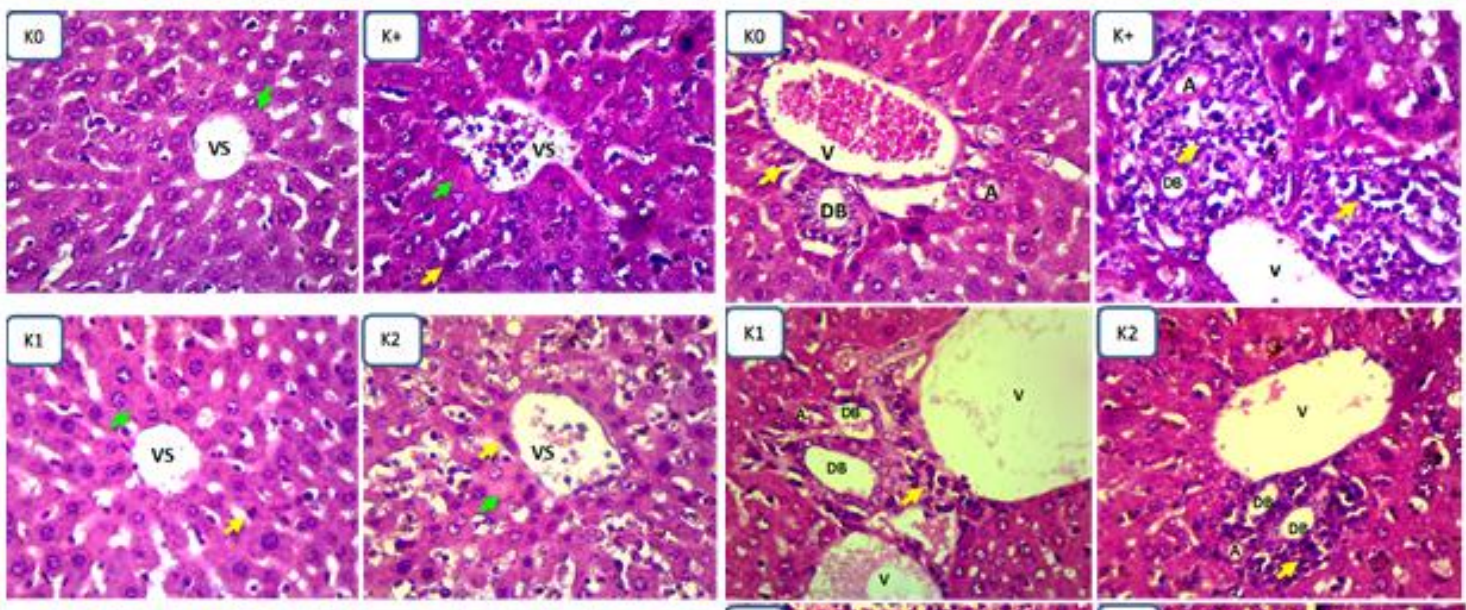

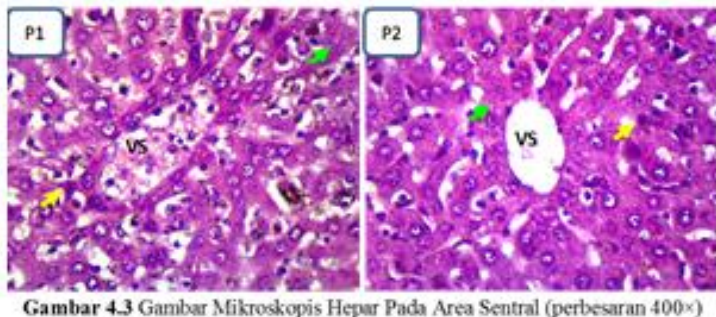

Gambar 4.3 Gambar Mikroskopis Hepar Pada Area Sentral (perbesaran 400 Keterangan : VS - vena sentralis, panah hijau - degenerasi sel hepar, panah kuning $=$ neitrosis sel hepar

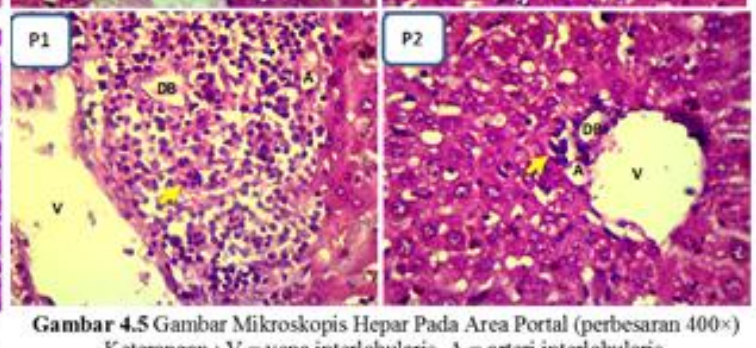

Keterangan : $\mathrm{V}=$ vena interlobularis, $\mathrm{A}=$ arteri interlobularis, $\mathrm{DB}$ = duktus biliverus, panah kuning, = Sel radang

\section{PEMBAHASAN}

Hepar mencit yang diterapi kombinasi menggunakan klorokuin dan ekstrak daun juwet lebih banyak mengalami degenerasi dan nekrosis dibandingkan dengan mencit yang hanya diterapi menggunakan klorokuin. Hal tersebut diduga pada pemberian terapi kombinasi, kerja organ hepar diperberat dengan pemberian nanopartikel ekstrak daun juwet. Selama infeksi berlangsung, hepar selain melakukan pertahanan melawan parasit juga diperberat dengan metabolisme bahan aktif serta proses detoksifikasi yang terjadi pada organ hepar (Louei and Salati, 2012). Kandungan bahan aktif dalam nanopartikel ekstrak kasar daun juwet, yakni $\beta$-sitosterol, betulinic acid, flavonol glikosida, asam flavonol glikosida, triterpenoid dan tanin, eicosane, octacosane, octadecane, serta pada daun juga kaya akan minyak esensial berupa pinocarveol, aterpeneol, myrtenol, eucarvone, muurolol, a-myrtenal, cineole, geranyl acetone, a-cadinol dan pinocarvone
(Ramya, et al., 2012). Disamping itu pada mencit yang diterapi menggunakan klorokuin tidak banyak terdapat gambaran degenerasi dan nekrosis. Hal tersebut diduga karena pada pemberian klorokuin terjadi kematian parasit yang berakibat pada penurunan jumlah parasit yang menginfeksi eritrosit sehingga jumlah eritrosit yang mengandung hemoglobin untuk suplai oksigen pada sel-sel hepar masih mencukupi.

Penelitian ini pun juga menunjukkan bahwa mencit yang diterapi menggunakan nanopartikel ekstrak daun juwet juga mengalami degenerasi dan nekrosis lebih parah dibandingkan dengan mencit yang diterapi menggunakan ekstrak daun juwet. Hal tersebut kemungkinan dikarenakan ukuran partikel ekstrak daun juwet dalam ukuran nano dapat meningkatkan kelarutan serta absorbsi obat dalam saluran cerna, sehingga bahan aktif yang sampai pada hepar untuk dibentuk menjadi metabolit aktifnya lebih banyak (Bilia, et al., 2014). 
Zat yang memasuki tubuh melalui rute oral akan masuk sistem saluran pencernaan. Sistem pencernaan terdiri dari berbagai bagian seperti rongga mulut, kerongkongan, lambung, usus kecil, dan usus besar. Zat di sana dipecah menjadi molekul-molekul kecil yang dapat diabsorbsi melalui epitel dan memasuki sirkulasi sistemik (Tortora and Grabowski, 2003). Setelah pemberian oral, zat harus melewati selsel epitel saluran cerna dan mencapai sirkulasi sistemik untuk memberikan efek farmakologis. Pemberian obat melalui oral merupakan cara pemberian obat yang paling mudah, karena obat melalui saluran yang sudah ada dan tidak merusak jaringan. Pemberian ekstrak daun juwet dalam ukuran nano mengakibatkan peningkatan luas permukaan. Hal tersebut mengakibatkan peningkatan kontak dengan permukaan epitel yang akan menyebabkan absorbsi partikel lebih banyak (Pridge, et al., 2015). Tampak dari sediaan histopatologi sel hepar yang diterapi ekstrak daun juwet dalam ukuran nanopartikel lebih banyak yang mengalami degenerasi dan nekrosis, dimana setiap perubahan ukuran dan bentuk nukleus hepatosit dianggap sebagai tanda peningkatan aktivitas metabolisme (Rahmawati dan Sriwidodo, 2016; Patel and Bahadur, 2011).

Sel radang merupakan salah satu sistem pertahanan dan perlawanan tubuh terhadap segala sesuatu yang bersifat menyerang tubuh serta sebagai respon terhadap cedera (Yang, et al., 2014). Infiltrasi sel radang pada area portal sebagian besar terdiri dari limfosit dan sel plasma seperti hasil penelitian yang telah dilakukan oleh Viriyavejakul, et al. (2014). Limfosit terdiri dari dua macam yaitu sel $\mathrm{T}$ dan sel $\mathrm{B}$. Limfosit $\mathrm{T}$ dengan mengaktivasi sel fagosit dibantu oleh berbagai sitokin yang dihasilkan oleh ThI berperan untuk mengeliminir parasit intraseluler, baik dalam hepatosit maupun dalam eritrosit. Imunitas pada stadium eksoeritrositer intrahepatik terutama dilakukan oleh limfosit T sitotoksik CD8 yang merusak hepatosit yang terinfeksi parasit baik secara langsung maupun secara tidak langsung melalui perantara sitokin-sitokin (Hidayati dan Akrom, 2003). Pada pewarnaan HE keduanya tampak dengan inti berbentuk oval atau bulat hampir memenuhi sel serta sitoplasma tampak sedikit (Arimbi, dkk., 2015).

Pada mencit yang terinfeksi Plasmodium dan diterapi kombinasi menggunakan klorokuin serta nanopartikel ekstrak daun juwet terdapat penurunan infiltrasi sel radang pada hepar. Hal tersebut menunjukkan bahwa selain daun juwet memiliki aktivitas antiplasmodial juga memiliki aktivitas sebagai antiinflamasi. Minimalnya infiltrasi sel radang pada mencit yang diterapi kombinasi menyebabkan reactive oxygen species (ROS) yang dihasilkan minimal pula, sehingga minimalnya peningkatan ROS tidak mengacu pada keadaan stress oksidatif (Schieber and Chandel, 2015). Inflamasi portal yang minimal pada mencit yang diterapi kombinasi menggunakan klorokuin dan nanopartikel ekstrak daun juwet menunjukkan bahwa pemberian nanopartikel ekstrak daun juwet (Syzygium cumini) sebagai terapi ajuvan obat klorokuin mampu mengurangi komplikasi yang lebih berat terkait penyakit malaria (Varo, et al., 2018).

Pada mencit yang terinfeksi Plasmodium dan diterapi kombinasi menggunakan klorokuin serta nanopartikel ekstrak daun juwet terdapat akumulasi pigmen hemosiderin yang minimal. Hal tersebut diduga akibat dari mekanisme kerja obat klorokuin membentuk kompleks dengan ferryprotoporphyrin (FP-IX) sehingga sangat toksik bagi parasit dan tidak dapat bergabung membentuk pigmen hemozoin. Toksin kompleks obat FP-IX meracuni vakuola 
menghambat ambilan (intake) makanan sehingga parasit mati kelaparan. Kompleks klorokuin juga mengganggu permeabilitas membran parasit dan pompa proton membran. Klorokuin juga bersifat basa lemah sehingga, masuknya klorokuin ke dalam vakuola makanan yang bersifat asam akan meningkatkan $\mathrm{pH}$ organel tersebut. Perubahan $\mathrm{pH}$ akan menghambat aktivitas aspartase dan cysteinase protease yang terdapat di dalam vakuola makanan sehingga metabolisme parasit terganggu. Disamping itu mekanisme kerja obat klorokuin didukung oleh antioksidan dari nanopartikel ekstrak daun juwet yang berperan dalam melawan efek radikal bebas dengan cara menghambat peroksidasi lemak sehingga dinding sel eritrosit menjadi lebih kuat dan tidak mudah ruptur (Tjahjani dan Khiong, 2010). Hal tersebut menyebabkan perkembangan dari parasit dapat dihambat sehingga sedikit pula hemoglobin yang terdegradasi hingga menyebabkan hemosiderosis.

Hemosiderin ialah pigmen $\mathrm{Fe}$, dalam makrofag berbagai jaringan berupa butiran/ granular, berasal dari destruksi eritrosit sedangkan hemosiderosis ialah timbunan bahan pigmen yang mengandung besi (hemosiderin) dalam tubuh secara berlebihan tetapi belum sampai mengakibatkan gangguan fungsi. Pada pewarnaan $\mathrm{HE}$ timbunan hemosiderin tampak berwarna kecoklatan yang terdapat dalam hepatosit dan sel Kupffer. Apabila terdapat sejumlah hemosiderin pada beberapa jaringan dapat dijadikan sebagai indikasi bahwa ditempat tersebut telah terjadi perdarahan hebat (Arimbi, dkk., 2015).

Berdasarkan hasil penelitian ini maka disarankan untuk dilakukan pemurnian bahan aktif yang terkandung dalam ekstrak kasar daun juwet (Syzygium cumini), sehingga efektifitas antioksidan yang terkandung dalam daun juwet sebagai terapi ajuvan obat klorokuin lebih maksimal dan tidak terlalu memperberat kerja organ hepar.

\section{KESIMPULAN}

Berdasarkan penelitian yang telah dilakukan dapat disimpulkan bahwa pemberian nanopartikel ekstrak daun juwet (Syzygium cumini) diperkirakan dapat meningkatkan kemampuan malarisidal saat fase eritrositik sebagai terapi ajuvan pada gambaran degenerasi, nekrosis, inflamasi portal, hiperplasia sel Kupffer, kongesti sinusoid serta hemosiderosis pada hepar mencit (Mus musculus) yang diinfeksi Plasmodium berghei.

\section{DAFTAR PUSTAKA}

Arimbi, A. Azmijah, R. Darsono, H. Plumeriastuti, T.V. Widiyatno, dan D. Legowo. 2015. Buku Ajar Patologi Umum Veteriner. Edisi 2. Airlangga University Press: Surabaya. Hal. 9-51.

Bilia, A.L., B. Isacchi, C. Righeschi, C. Guccione, M.C. Bergonzi. 2014. Flavonoids loaded in nanocarriers: an opportunity to increase oral bioavailability and bioefficacy. J. Food and Nutrition Sciences. 5: 1212-1227.

Harlev, A., A. Ashok, O.G. Sezgin, S. Amit, and S.P. Stefan. 2015. Smoking and Male Infertility: An Evidence-Based Review. World J. Mens Health. 33(3): 143-160. 
Hidayati, T. dan Akrom. 2003. Respon Imun pada Infeksi Malaria. Mutiara Medika. 3(2): 91-101.

Louei M.A. and A.P. Salati. 2012. The effect of Carthamus tinctorius L. on placental histomorphology and survival of the neonates in mice. Avicenna J. Med Phytomed. 2(3): 146-152.

Parhizgar, A.R. and A. Tahghighi. 2017. Introducing new antimalarial analouges of chloroquine and amodiaquine: a narrative review. Iran J. Med. Sci. 42(2): 115-128.

Pridge, E.M., F. Alexis, and O.C. Farokhzad. 2015. Polymericnanoparticle drug delivery technologies for oral delivery applications. Exp. Opin. Drug Deliv. 12(9): 1459-1473.

Rahmawati, R.P. dan Sriwidodo. 2016. Mekanisme Pembentukan Nanopartikel Kitosan. Jurnal Farmaka. 14(2): 356-374.

Ramadon, D. dan A. Mun'im. 2016. Pemanfaatan Nanoteknologi dalam Sistem Penghantaran Obat Baru untuk Produk Bahan Alam. Jurnal Ilmu Kefarmasian Indonesia. 14(2): 118-127.

Ramya, S., K. Neethirajan, and R. Jayakumararaj. 2012. Profile of bioactive compounds in Syzygium cumini- a review. J. of Pharmacy Research. 5(8): 4548-4553.
Resna, T.P. 2017. Pengaruh Pemberian Ekstrak Daun Duwet (Syzygium cumini) Terhadap Aktivitas Enzim Katalase Pada Tikus Hiperglikemia Yang Telah Diinduksi Aloksan [SKRIPSI]. Fakultas Kedokteran Universitas Andalas Padang. Hal. vii.

Schieber, M. and N.S. Chandel. 2015. ROS Function in Redox Signaling and Oxidative Stress. J. National institute of Health. 24(10): 1-25.

Soulard, V., H.B. Vanga, A. Lorthiois, C. Roucher, J.F. Franetich, G. Zanghi, M. Bordessoulles, M. Tefit, M. Thellier, S. Morrosan, G.L. Naour, F. Capron, H. Suemizu, G. Snounou, A.M. Sabater, and D. Mazier. 2015. Plasmodium falciparum full life cycle and Plasmodium ovale liver stages in humanized mice. Nature Communications. 6(7690): 1-9.

Tjahjani, S. dan K. Khiong. 2010. Potensi Buah Merah (Pandanus conoideus Lam.) Sebagai Antioksidan Dalam Mengatasi MlariaPada Mencit Strain BALB/C. J. of The Indonesian Medical Association. 60(12): 571-575.

Tortora G.J. and S.R. Grabowski. 2003. Principles of anatomy and physiology. Twelvth ed. Wiley, New York. 
Varo, R., V.M. Crowley, A. Sitoe, L. Madrid, L. Serghides, K.C. Kain, and Q. Bassat. 2018. Adjunctive Therap for Severe Malaria: A Review and Critical Apprasial. Malaria J. 17(47): 1-18.

Viriyavejakul, P., V. Khachonsaksumet, and C. Punsawad. 2014. Liver Changes in Severe Plasmodium Falciparum Malaria: Histopathology, Apoptosis and Nuclear Factor Kappa B Expression. Malaria J. 13(106): 1-9.

Weeratunga, P., G. Rhatanayake, A. Sivashangar, P. Karunanayake, A. Gnanathasan, and T. Chang. 2016. Plasmodium falciparum and Mycoplasma pneumoniae CoInfection Presenting with Cerebral Malaria Manifesting Orofacial Dyskinesia and Haemophagocytic Lymphohistiocytosis. Malaria J. 15(461): 1-3.
Yang, B., Z. Weiying, H. Zhenzhen, L. Fangming, Z. Ling, Y Shulong, K. Haibin, W. Lei, W. Jie, W. Jinglei, Z. Ting, and Z. Dalei. 2014. Involvement of oxidative stress and inflammation in liver injury caused by perfluorooctanoic acid exposure in Mice. BioMed Research International. p.1-7.

Yasueda, A., H. Urushima, and T. Ito. 2015. Efficacy and interaction of antioxidant supplements as adjuvant therapy in cancer treatment: a systematic review. Integrative Cancer Therapies. p. 123. 